Journal of Social Sciences (COES\&RJ-JSS)

ISSN (E): 2305-9249 ISSN (P): 2305-9494

Publisher: Centre of Excellence for Scientific \& Research Journalism, COES\&RJ LLC

Online Publication Date: $1^{\text {st }}$ October 2019

Online Issue: Volume 8, Number 4, October 2019

https://doi.org/10.25255/jss.2019.8.4.692.710

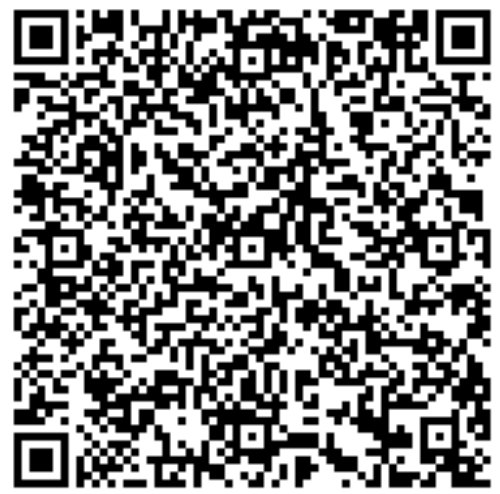

Successful Implementation of Corporate Governance Mechanisms in Banks

Dr. Abdullah Ahmed Aldaas

Middle East University, Amman, Jordan

adaas@meu.edu.jo

Dr. Suleiman Jamal Mohammad

Princess Sumaya University for Technology, Amman, Jordan

s.mohmmad@psut.edu.jo

Dr. Mohammad Yousef Abuhashesh

Princess Sumaya University for Technology (PSUT), Jordan

m.abuhashesh@psut.edu.jo

\title{
Abstract:
}

Corporate Governance is significant in managing the financial sector particularly banks of both the developing and the developed nations. Major corporate collapses worldwide revealed the presence of weak corporate governance system. The researcher conducted survey from the finance managers of the five commercial Jordanian banks which revealed that good corporate is significant for the performance of the banks. Good corporate governance balances the conflict of interest among the stakeholders. The participants believed that good corporate governance mechanisms such as transparency, privacy, legislations, code of conduct and clarity of procedures can enhance the efficiency of the banks. They believed that good corporate governance mechanisms effects the bank risks such as it protects the shareholders, stakeholders and reduces or transfers risk and ensures the stability of the economy. Hence, good corporate governance is essential for achieving success of the banking sector and in turn for the economic growth. The participants suggested that implementing good corporate governance in the banks leads to the integration of the capital markets, better solutions of the corporate governance issues and helps in building trust, integrity and transparency.

\footnotetext{
This work is licensed under a Creative Commons Attribution 4.0 International License.
} 


\section{Successful Implementation of Corporate Governance Mechanisms in Banks...}

Key Words:

Corporate Governance, Corporate Governance in banks, Corporate Governance mechanisms

\section{Citation:}

Aldaas, Dr. Abdullah Ahmed; Mohammad, Dr. Suleiman Jamal; Abuhashesh, Dr. Mohammad Yousef (2019); Successful Implementation of Corporate Governance Mechanisms in Banks; Journal of Social Sciences (COES\&RJ-JSS), Vol.8, No.4, pp:692-710; https://doi.org/10.25255/jss.2019.8.4.692.710.

\section{Introduction}

The corporate governance mechanism comprises of the rules, laws, regulations, institutes as well as the methodsvia which the corporates are regulated. It maintains balance amid the economic and the social goals as well as amid the communal and the individual objectives. It supports the efficient utilization of the resources and the accountability of the resources utilized during this process (Cadbury, 2000). The corporate policies comprises of the policies via which the companies are made responsive to the rights, needs and the demands of the stakeholders (Demb \& Neubauer, 1992; Alkalha et al., 2012; Al-Dmour et al., 2015; Al-dalahmeh et al., 2018; Abuhashesh et al., 2019 a,b). The Asian Development Bank (2000) regarded the Corporate Governance as a set of rules or mechanism that establishes the relationship amid the shareholders, managers, stakeholders and government. Kraft and Tirtiroglu (1998) defined Corporate Governance as the regulations that comprise of the rules, procedures andthe values that are implemented by shareholders, top management and the executive directors of the companies in performing tasks, transactions and operations of the companies. Macey (1995) defined Corporate Governance as the regulations that give rights to the shareholders, board members and executives in the management of the companies and financial institutions. The developed nations such as United States, United Kingdom, Germany, Japan, etc. have developed different models of Corporate Governance for boosting their economies. Corporate Governance is the system via which the organizations are directed, monitored and controlled. The structure of the corporate governance specifies the distribution of rights and responsibilities among organizations' varied actors such as board members, management, shareholders and stakeholders. A good Corporate Governance ensures the effective and efficient allocation of the resources of the organization.

Corporate Governance can be market based or bank centered relationship based. In the market based Corporate Governance, financing is provided by the investors while in bank centered Corporate Governance, financing comprises of a large portion of debt as well as equity (Prowse, 1996). A significant characteristic of these policies is the designing of the regulations, rules and practices that can govern and monitor the transactions going on in the banking sector. These 
practices are known as corporate governance of the banks. Transparency and accountability are the major characteristics of the Corporate Governance. The performance of organizations depends upon the Corporate Governance structure of the organizations. It comprises of both internal as well as external control procedures that are implemented by the organizations. An efficient Corporate Governance system is beneficial to the organizations in the long run. Corporate Governance is the enhancement of the long term shareholders' values, thereby protecting the interest of other stakeholders too. The framework for the Corporate Governance is concerned mainly with the executive as well as non-executive directors, distinction of CEO from the chairmanship, rights of all the shareholders comprising of the minority, accountability, risk management, etc. Hence, Corporate Governance comprises of all the monitoring activities, controlling procedures and accountability mechanisms employed in the organizations in order to attain the corporate objectives.

Effective Corporate Governance in the financial institutes is a means of mobilizing the capital with the efficient utilization of the resources of the companies as well as the economy (Mayer, 1998; AL-Syaidh et al., 2016). It gains the confidence of the domestic as well as the international investors as they feel satisfied that their investment is in safe hands. Good corporate governance also ensures the implementation of the legal compliance and unbiased decisions for the benefit of the companies. Good Corporate Governance gives the impression to the investors that the financial institutions are stabilized and it is safe to invest in them.

The major commercial banks of Jordan include Arab Bank, ABC Bank (Jordan), Bank of Jordan, Cairo Amman Bank, Capital Bank, Jordan Commercial Bank, Jordan Kuwait Bank, Jordan Ahli Bank, The Housing Bank for Trade \& Finance Arab Jordan Investment Bank, Invest Bank, Société Générale and Bank al Etihad. The current research has examined the role played by the Corporate Governance in the banking sector particularly Jordan It has covered all the pros and cons related to the structure and the functioning of the Corporate Governance in the banking sector.

\subsection{Problem Statement}

Corporate Governance is vital in managing the financial sector of both the developing and the developed nations. Several researchers have studied the role played by the Corporate Governance in the banking sector of the developed nations. However, there is dearth of literature on the role played by the Corporate Governance in the banking sector of the developing nations. This research will particularly focus on the role played by the Corporate Governance in the Jordan Banking sector. Corporate Governance is still in its initial stages in 


\section{Successful Implementation of Corporate Governance Mechanisms in Banks...}

Jordan and regulatory bodies are concerned about the proper implementation of the Corporate Governance in the companies of Jordan particularly in the Banking sector. The principles of the Corporate Governance depend upon ensuring transparency, accountability and responsibility in the corporate sector. Implementation of Corporate Governance regulations is even more important in the banking sector as transparency and impartiality are the requirements of the banking sector. So, this study will explore the challenges and hurdles faced by the banking sector in Jordan in order to practice the Corporate Governance rules and regulations. The current study will measure the impact of Corporate Governance on the performance of the financial institutions in the Jordan. It will cover all the pros and cons related to the structure and the functioning of the Corporate Governance in the banking sector of Jordan.

According to the World Bank (2003), the accounting rules and practices are not enforced in the developing nations. Lack of professional ethics and ineffective policy implementation leads to weak Corporate Governance (Uddin, 2005). There is a need for the professional bodies in developing nations to enforce the implications of the accounting rules and regulations in the companies so that the structure and functioning of the Corporate Governance in the companies can be improved.

\subsection{Objectives of the Study}

Following are the objectives of the study:

1. To investigate the purpose and the impact of the regulations and policies of Corporate Governance on the banking sector of the developing nations.

2. To investigate the factors that lead to the successful implementation of Corporate Governance mechanism in the banking sector particularly Jordan.

3. To investigate the challenges and hurdles faced by organizations in implementing a good Corporate Governance system.

\subsection{Research Methodology}

The present research article comprises of the Qualitative research methodology. The qualitative research methodology has involvedboth primary as well as secondary sources of data collection. The primary source has comprised of survey from the five commercial banks of Jordan. Opinion of one financial manager from each bank was obtained through the semi-structured questionnaires. Hence, Convenient Purposive sampling method has been used by the researcher for the survey. The secondary source has comprised of review of books, journals, articles, magazines, organizational reports, case studies and authentic websites.

\subsection{Cases of Major Corporate Collapses Worldwide}

Following are the cases of major corporate collapses that occurred throughout 
the world:

The first ever recorded case in the history of banking sector was that of the Medici Bank in 1494 in Italy (Raymond, 1948). The bank ended up in large debts due to the inability of the bank to control lavish spending of the directors and managers. As a result of which, the bank underwent bankruptcy. In 1931, the German bank Danat bank (Norddeutsche Wollkammeri and Kammgarn spinnerei) faced bankruptcy. After the Great Depression, there began rumors related to the solvency of the bank (Isabel, 2004). There occurred a bank run and the bank Danat bank was forced into insolvency. In 1983, the collapse of the Carrian Group, a Hong Kong conglomerate, was the largest in the history of Hong Kong. This group owned real estate business and other businesses such as insurance, hotels, transport, taxi, etc. (Cromie, 1986). It occurred due to an accounting fraud. In this case, an auditor was murdered and an advisor committed suicide.

In 1987, the American oil subsidiary Chevron Corporation, Texaco Inc. went into bankruptcy after undergoing a legal battle with the Pennzoil (Tierney, 2007). It owed a debt of $\$ 10.5 \mathrm{bn}$. Later on, the company was resurrected and taken over by the Chevron Corporation.

In 2009, after the financial crisis of 2007 to 2008, the Anglo Irish Bank was forced to be nationalized by the government of Ireland. The total loans granted to the directors were higher than $€ 255$ million (Carolan, 2012). The bank was sued by the private investors for $\$ 23$ million.

In 2001, Enron scandal emerged as a result of the corruption in the Enron Corporation, which is an American energy, commodities and services based corporation (Sherman, 2002). This scandal questioned the accounting rules and practices in several corporations in the United Sates.

Hallmark is the largest banking scam that has occurred in the banking sector of Bangladesh. It occurred to the weak Corporate Governance system in the banking sector of Bangladesh. The Sonali Bank of Bangladesh was involved in giving a loan of Tk 2,686.14 to the Hallmark group (Joseph, 2011). The fraud was detected in 2012 and the top management of the Sonali Bank was found to be involved in the corruption.

Proper implementation of the Corporate Governance rules and regulations would have prevented the above cases of fraud and corruption. Hence, this shows that there is a dire need that companies and banks should strictly implement the Corporate Governance rules and regulations in order to comply with the international standards. This will prevent cases of fraud and will also attract the foreign investors. 


\section{Successful Implementation of Corporate Governance Mechanisms in Banks...}

\section{Literature Review}

Numerous researchers have written literature related to the Corporate Governance in the financial industry of the developed nation. However, there is lack of literature on the role played by the Corporate Governance in the banking industry of the developing nation. This research had specifically focused on the banking sector of the developing nations and compared it with that of the developed nations. Following is the review of some of the researches carried out on the role of the Corporate Governance in the financial institutions:

According to Moudud (2015), the Conventional Banks and the Islamic Banks are practicing the Corporate Governance (CG) guidelines and regulations, as both the banking sectors are facing significant improvement in their functioning. As compared to the Conventional Banks, the Islamic Banks are lacking behind in following the Corporate Governance practices (Moudud, 2015). According to Mahtab \& Abdullah (2016), Corporate Governance is a vital issue in the modern era. Good Corporate Governance leads to the positive influence on the financial institutions. According to Sobhan and Werner (2003), the State Owned Enterprises (SOE) do not consider them as corporate, as they do not follow any requirements for the implementation of the Corporate Governance regulations. Due to the State Owned Enterprises and lack of foreign investors, there is no push from the international community on the financial institutions of the developing nations to implement good Corporate Governance.

According to Rashisd, Rudkin and Zoysa (2015), there are two models that are followed for practicing the Corporate Governance, that is, Anglo American Model and German Japanese Model.The researchers identified six weaknesses related to the implementation of Corporate Governance in the developing nations, that is, weak framework of regulations, lack of Corporate Governance culture, concentration of individual investors, weak control of institutions, lack of foreign investors and weak transparency. Hossain and Reaz (2007) mentioned in their article entitled "The Determinants and Characteristics of Voluntary Disclosure by Indian Banking Companies" that three significant problems encountered by the researchers in the disclosure related research arerecognizing and comprehending the factors affecting the decisions of the managers regarding disclosure related issues,comprehending the beneficial aspects in predicting the disclosure levels, and thirdly improving the quality of companies' reports in terms of non-financial information. These factors can be further classified into three types, that is common contextual factors, corporate features and internal relative factors (Adams, 2002).

According to Kamal, Pervin and Alam (2007), the banking sector acts as a dominant financial intermediary in the financial system of the developing countries due to the underdeveloped capital markets, limited availability of 
financial instruments and lack of the confidence in the financial system. The banks play an intermediary role in providing stability to the financial system of the developing countries. The developing countries have implemented policies for developing and restructuring the banking sector. An important feature of these policies is the designing of the regulations, rules and practices for governing and monitoring the transactions going on in the banking industry. Llewellyn (2007) focused on studying corporate governance in non-incorporated financial firms. The author describes the relevant stakeholders and the nature of agency problems in different types of financial firms. He compares monitoring mechanisms, incentives, abilities and feasibilities of managers and members of mutuals. Mutuality raises specific corporate governance issues: Corporate governance is less clearly defined because the firm's objectives are less clearly defined. Conflicts of interest between managers and owners are less easily identified and it is more difficult to create management incentives. The almost exclusive source of capital is retained profits and each member has a nonexclusive and non-marketable claim to residual net worth. Voting rights are typically not proportional to the size of the ownership stake. There is no market in ownership claims and therefore no effective market in corporate control. Consequently, there is ample scope for mutuals to be inefficient. There is, however, no evidence that the efficiency and performance of mutuals are poorer that that of incorporated financial firms.

According to Mahtab \& Abdullah (2016), Corporate Governance is a vital issue in the modern era. Good Corporate Governance leads to the positive influence on the financial institutions. Keeping in view the present situation of the financial institutions of Bangladesh, it has become significant for Bangladesh to pay attention to it. The research is based upon the empirical findings and the theoretical framework. The study measured the CG of the financial institution by utilizing financial data of fifteen private commercial banks in Bangladesh for a time period of five years, that is, from 2009 to 2014 . The variables that were utilized in the research included average return on assets, average return on equity, average technical efficiency, average allocative efficiency, etc. The results revealed positive relationship among the above mentioned variables.

\section{Data Analysis and Findings}

The analysis of the survey conducted from the financial managers of the five commercial banks of Jordan is given below:

\section{1 Significance of Good Corporate Governance in Banks}

All the participants (100\%) believed in the significance of the good corporate governance for the banks. 
Successful Implementation of Corporate Governance Mechanisms in Banks...

Table 1: Significance of Good CG in Banks

\begin{tabular}{|c|c|c|}
\hline $\begin{array}{c}\text { Significance of Good } \\
\text { Corporate Governance }\end{array}$ & Frequency & Percentage \\
\hline Yes & 5 & $100 \%$ \\
\hline No & - & - \\
\hline Total & 5 & $100 \%$ \\
\hline
\end{tabular}

The participants believed that as the banking industry is very important to any economy, so, corporate governance is also significant for this industry. The rules and regulations linked with the corporate governance are advantageous to the bankas well as the stakeholders of the banks. Corporate governance reduces subjectivity and focuses on institutionalism. Corporate governance also identifies authorities and responsibilities, tries to attain neutrality and frees the system from biasness. The participants believed that the corporate governance is crucial for the survival of the banking industry. If consumers stop trusting their financial institutions it will result in bank failures as evident during the latest financial crisis in 2008. Good corporate governance avoids misconduct of operations. Good corporate governance results in improved board structures, administrative procedures and transparent disclosure requirements that results in bettergoverrned banks, which are more likely to allocate investments proficiently. Hence, strong corporate governance can be an important pillar for the banking sector.

\subsection{Corporate Governance Mechanisms that can Improve the Efficiency of the Banks}

The participants gave multiple response in describing the corporate governance mechanisms that can improve the efficiency of the banks. $20 \%$ of the participants believed that the corporate governance mechanisms such as discipline, committee of audit, code of conduct, privacy and clarity of procedures for selecting top and medium management levels are necessary for improving the efficiency of the banks. $40 \%$ of the participants believed that committee of audit, legislations and instructions and fairness are the corporate governance mechanisms that can enhance the efficiency of the banks.

Table 2: CG Mechanisms that can improve the Efficiency of the Banks

\begin{tabular}{|c|c|c|}
\hline $\begin{array}{c}\text { Selected Governance } \\
\text { Mechanisms }\end{array}$ & Frequency & Percentage \\
\hline Discipline & 1 & $20 \%$ \\
\hline Transparency & 2 & $40 \%$ \\
\hline Committee of audit & 1 & $20 \%$ \\
\hline Legislations and instructions & 2 & $40 \%$ \\
\hline Code of conduct & 1 & $20 \%$ \\
\hline
\end{tabular}


Journal of Social Sciences (COES\&RJ-JSS), 8(4), pp.692-710

\begin{tabular}{|c|c|c|}
\hline Privacy & 1 & $20 \%$ \\
\hline Fairness & 2 & $40 \%$ \\
\hline $\begin{array}{c}\text { Clarity of procedures for } \\
\text { selecting top and medium } \\
\text { management levels }\end{array}$ & 1 & $20 \%$ \\
\hline
\end{tabular}

The participants of the survey believed that discipline, transparency and fairness are significant for the financial institutions. The participants also shared that the mechanism of the banks should be transparent while dealing with the depositors and the shareholders. Their rights should be protected through insurance and regulations.

\subsection{Influence of the Ownership Structure and Board of Directors Upon the Governance Mechanisms of the Banks}

All of the participants, that is, $100 \%$ believed that the ownership structure and the board of directors influences the governance mechanisms of the banks.

Table 3: Influence of the Ownership Structure and Board of Directors Upon the CG of the Banks

\begin{tabular}{|c|c|c|}
\hline $\begin{array}{c}\text { Influence of the Ownership Structure } \\
\text { and Board of Directors }\end{array}$ & Frequency & Percentage \\
\hline Yes & 5 & $100 \%$ \\
\hline No & - & - \\
\hline Total & 5 & $100 \%$ \\
\hline
\end{tabular}

The participants believed that corporate governance should be implemented in all the organizational structure of the bank, starting from the top management to the lowestmanagement. It should be incorporated in the bank mission statement, their vision and their strategy. The ownership structure and the board of directors effects the governance mechanisms of the banks as the board of directors has the power to hire, terminate, compensate top management and to take decisions for achieving the goals of the organization. They safeguard the organization's assets and invested capital. Hence, the role of board as a mechanism for corporate governance of banks takes on special relevance in a framework of limited competition, intense regulation, and higher informational asymmetries due to the complexity of the banking business.

\subsection{Effect of Interaction between Governance and Different Institutions upon the Corporate Governance Mechanisms of the Banks}

Majority of the participants, that is, $60 \%$ believed that the interaction between the governance and different institutions influences the corporate governance mechanisms of the banks, while the rest of the $40 \%$ did not believe in that. 
Successful Implementation of Corporate Governance Mechanisms in Banks...

Table 4: Effect of Interaction Between Governance and Different Institutions upon the CG Mechanisms of the Banks

\begin{tabular}{|c|c|c|}
\hline $\begin{array}{c}\text { Interaction Between Governance and } \\
\text { Different Institutions }\end{array}$ & Frequency & Percentage \\
\hline Yes & 3 & $60 \%$ \\
\hline No & 2 & $40 \%$ \\
\hline Total & 5 & $100 \%$ \\
\hline
\end{tabular}

The participants believed that the governance must interact with other institutions in order to achieve success and continuity of the corporate .It reduces the level of competition and assists the organizations in implementing the rules and regulations properly. A bank needs to balance corporate governance mechanisms (conformance) with performance by adopting strategic decisions and risk management with the efficient utilization of the organization's resources.

\subsection{Corporate Governance Issues Faced by the Banks}

$60 \%$ of the participants gave multiple response while listing the corporate governance issues faced by the banks, while, $40 \%$ of them did not give any response. Out of the $60 \%$ who responded, $40 \%$ of them believed that the corporate government issues faced by the banks include transparency and accountability. $20 \%$ of the participants believed that integrity, public disclosures, credibility and adhering to the regulations are the major corporate governance issues.

Table 5: CG Issues Faced by the Banks

\begin{tabular}{|c|c|c|}
\hline Corporate Governance Issues & Frequency & Percentage \\
\hline Transparency & 2 & $40 \%$ \\
\hline Accountability & 2 & $40 \%$ \\
\hline Integrity & 1 & $20 \%$ \\
\hline Public Disclosures & 1 & $20 \%$ \\
\hline Credibility & 1 & $20 \%$ \\
\hline Adhering to the regulations & 1 & $20 \%$ \\
\hline No response & 2 & $40 \%$ \\
\hline
\end{tabular}

\subsection{Effect of Corporate Governance Mechanisms on the Bank Risks}

The participants gave multiple responses while describing the effect of corporate governance mechanisms on the bank risks. $40 \%$ of the participants believed that good corporate governance mechanisms effects the bank risks such as it protects the shareholders, stakeholders and reduces or transfers risk. $20 \%$ of the 
participants believed that appropriate risk management techniques and structures ensure the stability of the economy.

Table 6: Effect of CG Mechanisms on the Bank Risks

\begin{tabular}{|c|c|c|}
\hline Effect of CG on the Bank Risks & Frequency & Percentage \\
\hline Protects Shareholders & 2 & $40 \%$ \\
\hline $\begin{array}{c}\text { Protects Stakeholders } \\
\text { (employees, customers, public } \\
\text { and supervisors) }\end{array}$ & 2 & $40 \%$ \\
\hline $\begin{array}{c}\text { Reduces or transfers risk } \\
\text { Appropriate risk management } \\
\text { techniques and structures } \\
\text { ensures the stability of the } \\
\text { economy }\end{array}$ & 2 & $40 \%$ \\
\hline
\end{tabular}

\subsection{Corporate Governance mechanisms that Prevent Excessive Risk Takings in} the Banks

$80 \%$ of the participants gave multiple responses and believed that different corporate mechanisms can prevent excessive risk takings in the banks. $20 \%$ of the participants did not response. Out of the $80 \%$ who responded, $60 \%$ of them believed the good internal auditor control is the corporate governance mechanism that prevents excessive risk taking in the banks. $40 \%$ of the participants also believed that clear procedures for all aspects of bank business/disclosure and transparency system are the mechanisms that prevent the excessive risk takings in the banks. Out of these participants, $20 \%$ also believed that independent management and prudent underwriting for loans prevents excessive risk to be taken.

Table 7: CG Mechanisms that Prevent Excessive Risk Takings in the Banks

\begin{tabular}{|c|c|c|}
\hline $\begin{array}{c}\text { CG Mechanisms that Prevent } \\
\text { Excessive Risk Takings }\end{array}$ & Frequency & Percentage \\
\hline Independent management & 1 & $20 \%$ \\
\hline Independent Audit committee & 2 & $40 \%$ \\
\hline Good Internal auditor control & 3 & $60 \%$ \\
\hline $\begin{array}{c}\text { Prudent underwriting for loans } \\
\text { prevent excessive risk taken }\end{array}$ & 1 & $20 \%$ \\
\hline $\begin{array}{c}\text { Clear procedures for all aspects of } \\
\text { bank business/Disclosure and } \\
\text { Transparency system }\end{array}$ & 2 & $40 \%$ \\
\hline No response & 1 & $20 \%$ \\
\hline
\end{tabular}




\section{Successful Implementation of Corporate Governance Mechanisms in Banks...}

The participants also suggested that the banks should have good internal systems that can monitor its capital adequacy. The internal control system will be different from one bank to another depending upon the size and structure of the banks.There is a need for the availability of a disclosure and transparency system that can drive the banks to pay attention to the improvement of the asset and liability management. It will also assist in gaining customer confidence, capital adequacy standard and will facilitate the audit review process.

\subsection{Opportunities and Constraints Affect the Corporate Governance Mechanisms in Banks}

$100 \%$ of the participants believed that opportunities and constraints affect the corporate governance mechanisms in the banks.

Table 8: Opportunities and Constraints Affect the CG Mechanisms in Banks

\begin{tabular}{|c|c|c|}
\hline $\begin{array}{c}\text { Opportunities and } \\
\text { Constraints Effect CG }\end{array}$ & Frequency & Percentage \\
\hline Yes & 5 & $100 \%$ \\
\hline No & - & - \\
\hline Total & 5 & $100 \%$ \\
\hline
\end{tabular}

The participants believed thatif the banks do not follow the bank polices then it can affect the performance of the banks. For example, not following the bank policy in lending can cause lenders to make risky loans which in turn can affect the shareholders, consumers and the community at large such as the predatory lending in the mortgage industry. The opportunities and constraints in banks differ case by case. Theoretically, strict regulatory environments may promote firm-level governance that is effective in controlling for agency cost so that a complementary relationship exists amidthe governance and the regulation. The presence of regulationscaninfluence the design of internal governance mechanisms and their impact upon the performance of the firms.

\subsection{Changes in the Corporate Governance Mechanisms Influences the Performance of the Banks}

$80 \%$ of the participants believed that changes in the corporate governance mechanism influences the performance of the banks, while, $20 \%$ of them did not give any response. Out of the $80 \%$ who responded, $20 \%$ of them believed that systematic control in the corporate mechanism can affect the performance of the banks. Another $20 \%$ believed that changes in the corporate governance mechanisms can lead to the profitability of the banks and reduces their chances of failure. $20 \%$ also believed that changes in the corporate governance can improve the morality of the employees and enhances the clients' satisfaction. $20 \%$ of the participants also believed that changes in the corporate governance mechanism enhance the performance of the banks. 
Table 9: Changes in the CG Mechanisms Influences the Performance of the Banks

\begin{tabular}{|c|c|c|}
\hline Changes in CG Effects Banks & Frequency & Percentage \\
\hline $\begin{array}{c}\text { Systematic Control } \\
\text { Banks will be profitable and no chances } \\
\text { of failure }\end{array}$ & 1 & $20 \%$ \\
\hline $\begin{array}{c}\text { Improves morality of employees and } \\
\text { enhances clients' satisfaction }\end{array}$ & 1 & $20 \%$ \\
\hline Performance of the bank will increase & 1 & $20 \%$ \\
\hline No response & 1 & $20 \%$ \\
\hline Total & 5 & $100 \%$ \\
\hline
\end{tabular}

Theparticipants believed that corporate governance is a system that control all the procedures in the banks so, if it is followed in all the aspects itcan make all the transactions and procedures systematic. The managers of the banks need to understand that there exists an association between corporate governance and the organizational performance. If managers understand this significant association, they are more likely to govern the banks effectively.

3.10 Corporate Governance Mechanisms acts as the Relation Amid the Firm's Capital Providers (Shareholders) and Board of Directors/Top Management of the Banks

Majority of the participants, that is, $60 \%$ believed that corporate governance mechanisms acts as the relation amid the firm's capital providers (shareholders) and board of directors/top management of the banks. $20 \%$ of the participants replied in negative while $20 \%$ of the participants did not give any response.

Table 10:CGMechanisms acts as the Relation Amid the Firm's Capital Providers (Shareholders) and Board of Directors/Top Management of the Banks

\begin{tabular}{|c|c|c|}
\hline $\begin{array}{c}\text { CG as a Relation Amid the } \\
\text { Shareholders and Board of } \\
\text { Directors/Top Management }\end{array}$ & Frequency & Percentage \\
\hline Yes & 3 & $60 \%$ \\
\hline No & 1 & $20 \%$ \\
\hline No response & 1 & $20 \%$ \\
\hline Total & 5 & $100 \%$ \\
\hline
\end{tabular}

The participants believed that well managed corporate governance develops the relationship between the various departments in banks as well as increases the harmony between the various parts in the banking sector. Corporate governance also contributes to the integration of the interests of the management, 


\section{Successful Implementation of Corporate Governance Mechanisms in Banks...}

shareholders and other stakeholders. Weak corporate governance allows managers to do what they prefer to, which could be at the expense of equity holders, eg: taking excessive debts, etc. On theoretical grounds, corporate governance can have an impact on the firm's capital structure. If it is assumed that the capital structure is partly determined by the firm's risk profile then this leads to the field of the agency theory. This theory tries to align the divergent interests of principals (shareholders) and agents (management). It is highly probable that the risk profiles of these groups will be different. Thus, corporate governance mechanisms would try to align the financing behavior of the executives with the return targeted (and thus the risk assumed) by the owners of the banks or companies.

3.11 Corporate Governance Mechanisms Balances the Interests of the Shareholders, Management, Customers, Government, Financial Institutions and the Community

$80 \%$ of participants who responded gave multiple responses while describing the corporate governance mechanisms that balance the interests of the shareholders, management, customers, financial institutions and the community. $20 \%$ of the participants did not respond. Out of $80 \%$ who responded, $40 \%$ of the participants believed that good corporate governance reduces the conflict of interest between the stakeholders and enhances transparency. $20 \%$ of the participants believed that it enhances the efficiency of the financial markets, reduces biasness and impacts all spheres of management from action plans to internal controls, performance measurement and corporate disclosure.

Table 11: CG Mechanisms Balances the Interests of the Stakeholders

\begin{tabular}{|c|c|c|}
\hline Balances the Interests & Frequency & Percentage \\
\hline Reduces conflict of interest & 2 & $40 \%$ \\
\hline Enhances Transparency & 2 & $40 \%$ \\
\hline $\begin{array}{c}\text { Enhances efficiency of the financial } \\
\text { markets }\end{array}$ & 1 & $20 \%$ \\
\hline $\begin{array}{c}\text { Reduces biasness } \\
\text { Impacts all spheres of management from } \\
\text { action plans to internal controls, } \\
\text { performance measurement and } \\
\text { corporate disclosure }\end{array}$ & 1 & $20 \%$ \\
\hline No response & 1 & $20 \%$ \\
\hline
\end{tabular}

The participants believed that corporate governance helps in achieving balance of interest as all the stakeholders have different objectives. So,it must balance their needs and wants and make sure that it does not create biasness. Corporate governance essentially involves balancing the interests of a company's stakeholders, such as shareholders, management, customers, suppliers, 
financiers, government and the community. Since corporate governance also provides the framework for attaining a company's objectives, it encompasses practically every sphere of management, from action plans and internal controls to performance measurement and corporate disclosure (Abuhashesh et al, 2019c).

\subsection{Good Corporate Governance Mechanisms Necessary for Achieving Success and Good Economic Growth}

All the participants (100\%) believed that good corporate governance is necessary for achieving success and good economic growth.

Table 12: Good CG Mechanisms Necessary for Achieving Success and Good Economic Growth

\begin{tabular}{|c|c|c|}
\hline $\begin{array}{c}\text { Success and Economic } \\
\text { Growth }\end{array}$ & Frequency & Percentage \\
\hline Yes & 5 & $100 \%$ \\
\hline No & - & - \\
\hline Total & 5 & $100 \%$ \\
\hline
\end{tabular}

According to the participants, good mechanism of corporate governance in banks enhances the efficiency of the bank, there by improving the whole economy. If the banks will not practice good corporate governance they will fail to perform well which can negatively affect the economy as banking sector plays a significant role in the economic growth. Good corporate governance seeks to make sure that all shareholders get a voice at general meetings and are allowed to participate equally. Institutional shareholders look at corporate governance system completely different from the real shareholders since institutions primarily have more valuable criteria than individuals and they, as experts, are better motivated to promote, develop and monitor the investments. Thus, they must take a more active role in directing the company than the shareholders. Having greater access to information and also having the authority and power in decision makings, they are able to more actively participate in monitoring the company's performance in order to achieve success and good economic growth.

\subsection{Reasons for the Implementation of Good Corporate Governance in the Banks}

The participants gave multiple response while describing the reasons for the implementation of good corporate governance in the banks. $40 \%$ of the participants believed that the major reason for implementing good corporate governance in banks is the deregulations and the integration of the capital markets, better solutions of the corporate governance issues and builds trust, integrity and transparency. $20 \%$ of the participants believed that it leads to 


\section{Successful Implementation of Corporate Governance Mechanisms in Banks...}

greater shareholer's activism and better management of the executives and the Board of Directors.

Table 13: Reasons for the Implementation of Good CG in the Banks

\begin{tabular}{|c|c|c|}
\hline $\begin{array}{c}\text { Reasons for the } \\
\text { Implementation of Good CG }\end{array}$ & Frequency & Percentage \\
\hline $\begin{array}{c}\text { Deregulations and the } \\
\text { integration of the capital } \\
\text { markets }\end{array}$ & 2 & $40 \%$ \\
\hline $\begin{array}{c}\text { Greater shareholder's } \\
\text { activism }\end{array}$ & 1 & $20 \%$ \\
\hline $\begin{array}{c}\text { Better solutions of the } \\
\text { corporate governance issues }\end{array}$ & 2 & $20 \%$ \\
\hline $\begin{array}{c}\text { Better management of the } \\
\text { executives and the Board of } \\
\text { Directors }\end{array}$ & 1 & $40 \%$ \\
\hline $\begin{array}{c}\text { Building trust, integrity and } \\
\text { transparency }\end{array}$ & 2 & \\
\hline
\end{tabular}

\section{Conclusion and Suggestions}

There is a dire need that banks and companies should strictly implement the Corporate Governance rules and regulations in order to comply with the international standards. This will prevent cases of fraud and will also attract the foreign investors. The finance managers of the Jordanian banks believed that good corporate is significant for the performance of the banks. They believed that good corporate governance mechanisms such as transparency, privacy, legislations, code of conduct and clarity of procedures can enhance the efficiency of the banks. They believed that the ownership structure and the board of directors influences the governance mechanisms of the banks. According to the views of the participants, the corporate governance issues faced by the banks comprises of transparency, integrity, accountability, credibility, public disclosures and adhering to the regulations. They considered that good corporate governance good corporate governance mechanisms effects the bank risks such as it protects the shareholders, stakeholders and reduces or transfers risk and ensures the stability of the economy. They believed that good corporate mechanisms such as independent management, good internal auditor control, independent audit committee and transparency can prevent excessive risk takings in the banks. Good corporate governance balances the conflict of interest among the stakeholders. Hence, good corporate governance is essential for achieving success of the banking sector and in turn for the economic growth. Also, researchers called for future research on the enabling factors of applying electronic services (e.g. Shannak et al., 2010; Maqableh et al., 2015; Abuhashesh et al., 2020; Al-Dmour et al., 2020) in enhancing better organizational outcomes. 
The participants suggested that implementing good corporate governance in the banks leads to the integration of the capital markets, better solutions of the corporate governance issues and will build trust, integrity and transparency. The participants suggested that strong Corporate Governance will enhance the efficiency of the banking sector and in turn the economy of the developing nations. The banking sector of developing nations would become competitive if good Corporate Governance would be implemented in the financial institutions. For attracting the foreign investment, there is a need that the financial institutions should improve their Corporate Governance system.

\section{References}

Abuhashesh, M., Al-Dmour, R., \& Masa'deh, R. (2019a). Factors that affect Employees Job Satisfaction and Performance to Increase Customers' Satisfactions. Journal of Human Resources Management Research, 1-23.

Abuhashesh, M., Al-Dmour, R., \& Masa'deh, R. (2019b). Factors that Impact Job Satisfaction and Performance among Employees in the Jordanian Industrial Sector. Proceedings of the 32nd International Business Information Management Association Conference, IBIMA 2018-Vision 2020: Sustainable Economic Development and Application of Innovation Management from Regional expansion to Global Growth, 4285-4305.

Abuhashesh, M., Al-Khasawneh, M., Al-Dmour, R., \& Masa'deh, R. (2020). The Impact of Facebook on Jordanian Consumers' Decision Process in the Hotel Selection. IBIMA Business Review, Forthcoming.

Abuhashesh, M., Mohammad, S.J., \& Al Khasawneh, M. (2019c). The Attitude of Jordanian Customers towards Virtual Stores. Int. J. Islamic Marketing and Branding, 4(1), 59-75.

Adams, C. A. (2002). Internal organizational factors influencing corporate social and ethical reporting: Beyond current theorizing. Accounting, Auditing \& Accountability Journal, 15(2), 223.

Al-dalahmeh, M., Khalaf, R., \& Obeidat, B. (2018). The Effect of Employee Engagement on Organizational Performance Via the Mediating Role of Job Satisfaction: The Case of IT Employees in Jordanian Banking Sector. Modern Applied Science, 12(6), 17-43.

Al-Dmour, R., Al Haj Dawood, E., \& Al-Dmour, H. (2020). The Effect of Customer Lifestyle Patterns on the Use of Mobile Banking Applications in Jordan. Int. J. Electronic Marketing and Retailing, Forthcoming. 


\section{Successful Implementation of Corporate Governance Mechanisms in Banks...}

Al-Dmour, R., Obeidat, B., \& Almajali, D. (2015). The Practice of HRIS Applications in Business Organizations in Jordan: An Empirical Study. 4th Scientific \& Research Conference on New Trends in Business, Management and Social Sciences (COES\&RJ-TK15/1).

Alkalha, Z., Al-Zu'bi, Z., Al-Dmour, H., \& Alshurideh, M. (2012). Investigating the Effects of Human Resource Policies on Organizational Performance: An Empirical Study on Commercial Banks Operating in Jordan. European Journal of Economics, Finance and Administrative Sciences, 51, 44-64.

AL-Syaidh, N., Al- Lozi, M., \& AlHarrasi, J. (2016). Transformational Leadership and its Role on the Effectiveness of Employees' Behavior: A Theoretical Study. Journal of Business \& Management (COES\&RJ-JBM), 4(1), 14-35.

Asian Development Bank. (2000). Promoting Good Governance: ADB's Medium Term Agenda and Action Plan. R-Paper. October 2000.

Cadbury, S. A. (2000). The Corporate Governance Agenda. Corporate Governance: An International Review, 8(1), 7-15.

Carolan, M. (2012). Investors sue Anglo for \$23m. Irish Times. November 2, 2009.

Cromie, A. (1986). Carrian fraud trial opens in Hong Kong. The Sydney Morning Herald. February 19, 1986.

Demb, A., \& Neubauer, F. F. (1992). The corporate board: Confronting the paradoxes. Long range planning, 25(3), 9-20.

Hossain, M., \& Reaz, M. (2007). The determinants and characteristics of voluntary disclosure by Indian banking companies. Corporate Social Responsibility and Environmental Management, 14(5), 274-288.

Isabel, S. (2004). The German twin crisis of 1931. Journal of Economic History, 64(3), 822-871.

Kamal, Y., Pervin, T. \& Alam, S. (2007). Corporate Governance in the Banking Sector of Bangladesh. The Bangladesh Accountant, 57(30), 73-81.

Kraft, E. \& Tirtiroglu, D. (1998). Bank efficiency in Croatia: A Stochastic - Frontier Analysis. Journal of Comparative Economics, 26, 282-300. 
Llewellyn, D. T. (2007). Corporate Governance Issues in Non-Shareholder Value Financial Institutions: A Case Study of Mutual Building Societies in the UK. SUERF and the Central Bank of Cyprus. Seminar: Corporate Governance in Financial Institution. 29th - 30th March 2007.

Macey, J. R. \& Miller, G. P. (1995). Corporate Governance and Commercial Banking: A Comparative Examination of Germany, Japan and the United States. Stanford Law Review, 48, 73-112.

Mahtab, N. \& Abdullah, M. (2016). Corporate Governance in Financial Institutions in Bangladesh: A Preliminary Study. Arabian Journal of Business Management Review, 6(22).

Maqableh, M., Rajab, L., Quteshat, W., Khatib, T., \& Karajeh, H. (2015). The Impact of Social Media Networks Websites Usage on Students' Academic Performance. Communications and Network, 7(4), 159-171.

Mayer, C. (1998). Financial Systems and Corporate Governance: A Review of the International Evidence. Journal of Institutional and Theoretical Economics, 154, 144-165.

Moudud-Ul-Huq, S. (2014). Corporate Governance Practices in Bangladesh: A Comparative Analysis between Conventional Banks and Islamic Banks. Int. J. Manag. Bus. Res., 5(1), 53-60.

Prowse, S. D. ((1996). Corporate Finance in International Perspective: Legal and Regulatory Influences on Financial System Development. Economic and Financial Policy Review, Q III, 2-15.

Rashid, A., Rudkin, K. \& Zoysa, A. D. (2015). Corporate Governance in Bangladesh: An Overview. University of Wollongong, Australia.

Raymond, A. D. (1948). The Medici Bank: Its Organization, Management and Decline. New York University Press.

Shannak, R., Obeidat, B., \& Almajali, D. (2010). Information Technology Investments: A Literature Review. Proceedings of the 14th IBIMA Conference on Global Business Transformation through Innovation and Knowledge Management: An Academic Perspective, Istanbul-Turkey, 1356-1368.

Sherman, S. (2002). Enron: Uncovering the Uncovered Story. Columbia Journalism Review, 40(6).

Sobhan, F. \& Werner, W. (2003). A Comparative Analysis of Corporate Governance in South Asia: Charting a Road Map for Bangladesh. Bangladesh Enterprise Institute.

Tierney, D. (2007). American men, American oil, American arms. FDR and Spanish Civil War: Neutrality and Commitment in the Struggle that Divided America. Duke University Press. p. 68. 